\title{
Social Media for Susi Pudjiastuti to Build Maritime Security Awareness in Indonesia
}

\author{
Andyna Sary \\ Program Pascasarjana, Institut Komunikasi dan Bisnis LSPR, Jakarta, Indonesia
}

\begin{abstract}
ABSTRAK
Indonesia menghadapi sejumlah tantangan serius dan mendesak dalam sektor ketahanan laut. Termasuk penangkapan ikan dan masuknya kapal asing secara liar, polusi sampah plastik, hingga berbagai kejahatan transnasional yang terorganisir seperti perdagangan manusia, penyelundupan narkotika, dan kerja paksa. Salah seorang figur politisi Indonesia yang mencuri perhatian dunia dengan kegigihannya memberantas pelanggaran tersebut ialah Susi Pudjiastuti, Menteri Perikanan dan Kelautan Republik Indonesia, periode 2014-2019. Artikel ini meneliti tentang strategi komunikasi Susi Pudjiastuti dalam memanfaatkan media sosialnya sebagai strategi utama demi membangun kesadaran akan pentingnya ketahanan laut di Indonesia. Melalui pendekatan mixed-methodology, secara kuantitatif dan kualitatif, penelitian ini berfokus pada pengukuran dan analisa konten pesan serta interaksi yang ada di Instagram dan Twitter Susi Pudjiastuti. Penelitian ini menggunakan teori komunikasi pemerintah oleh Canel \& Sanders, media baru oleh Marshall McLuhan, dan juga Humanistic Leadership Model oleh Robert Blake dan Jane Mouton. Dalam penelitian ini ditemukan hasil bahwa Susi Pudjiastuti telah membuat sebuat inovasi komunikasi politik dalam tataran birokrasi Indonesia yang kini menjadi lebih dekat, bersifat langsung tanpa perantara, dan transparan. Temuan lainnya menyatakan bahwa yang dilakukan oleh Susi Pudjiastuti bahkan menjadi tolak ukur bagi politisi dan pemimpin lainnya.
\end{abstract}

\begin{abstract}
Indonesia faces a number of serious and urgent challenges in the area of maritime security; including, Illegal, Unreported and Unregulated Fishing, Maritime Plastic Pollution, and serious Transnational Organized Crimes such as human trafficking and forced labor. One figure in Indonesian politics stands out for her efforts to eradicate these crimes, Susi Pudjiastuti, the Indonesian Minister for Marine Affairs and Fisheries since 2014. Minister Pudjiastuti has been remarkable both for her enforcement of previously-unutilized laws to seize and destroy illegal vessels, and her use of social media to promote awareness and action within the general public. The article takes a mixed-methodology approach to measure and analyze Pudjiastuti's strategic use of social media as a key weapon in her fight against crime in the maritime sector. This research used Governmental Communication Theory by Canel \& Sanders (2013), New Media by Marshall McLuhan, and also Humanistic Leadership Model by Robert Blake and Jane Mouton. Through quantitative and qualitative analysis of Pujiastuti's Instagram and Twitter posts, the thesis reveals a very high level of influence, awareness-raising and engagement with her message. The findings are that her innovative used of social media indicates a new paradigm of direct, transparent political engagement with the public that sets a high benchmark for other Indonesian leaders and politicians.
\end{abstract}

KATA KUNCI media sosial; komunikasi; politik; Susi Pudjiastuti; ketahanan laut; Indonesia

KEYWORDS

social media; communication; politics; Susi Pudjiastuti; maritime security; Indonesia 


\section{INTRODUCTION}

The rapid and fascinating movement of digital technology transforms us to a borderless global village. The world is seen as a massive and progressive community in which distance and isolation have been dramatically changed by the power of living in a cyber society. New media has been existing side by side to fill in the gap among conventional media. It is related closely with the benefits of an interconnected network, or simply to what we called the internet. The internet represents the newest, mostly wide discussed, and perhaps the most significant manifestation of new media (Flew, 2005). It comes in many different sophisticated platforms such as email, website, microblog, chatbot, ebook, mobile application, online gaming, video conferencing, video streaming, podcast, virtual reality, augmented reality, mixed reality environment, and for sure, social networking sites or as known as social media.

The rise of social media has been going on because it opens a huge possibility for people to create, to share, to participate, and to build their own types of creative content in daily basis (User-Generated Content). There are opportunities to exchange ideas, interacting with strangers or someone we have admired for so long, discover the latest information in order to avoid FoMO (Fear of Missing Out), express significant thoughts and feelings, and even let our voices to be heard. Eventually, the existence of social media allows us to interconnect each other in an easier way.

According to 2018 Global Digital Report by Global Web Index, Asian countries are leading the worldwide Broadband Mobile Connectivity, which allows social media to grow faster and wider (Kemp, 2018). Indonesia is no exception. Indonesian people started to get acquainted with social media frequently since the beginning of the 2000s. In line with mass media expansion after the 1998 reform movement. That includes social behavioral changing when people started to use a portable computer or gadget with no wires.

In terms of media usage, Indonesians started looking for two-way communication, an interactive and engaging platform, and a responsive tool that can be connected within distance and time. In 2018, statistically at least, there were more than 130,000,000 active social media users in Indonesia. That means almost $50 \%$ of the population has been contributing to this phenomenon (We Are Social, Hootsuite, 2018).

The government, especially politicians and state officials, will always require massive publicity and promotion, especially to run their program. Although conventional media like television, radio, and newspaper still do exist, they are no longer become the most reliable source for people. Not because they do not trustworthy, but simply because people demand more accessible and mobile information.

Based on the communication point of view, the usage of social media by politician or state officials is the latest form of political communication (Riaz, 2010). Not only during an 
election period but also during their term of service. One great example is coming from Ridwan Kamil, Governor of West Java, Indonesia. The only Indonesian who became one of The World's 50 Greatest Leaders by Fortune magazine in 2018 (Fortune, 2018). During his term of service, he also uses social media to share his working progress, to inform new policy, to let people talk to him for ideation, to complain if there is any violation, or even just to post his sense of humor online. As a result, he gained at least 10 million followers on Instagram and 3 million followers on Twitter until today. And most importantly, each channel has been utilized as an effective alternative tool of political communication.

So when common people use social media only to stay in touch, have fun, and keeping up with surrounding. Some politician or state officials came to the realization that this technology 2.0 can bring us way deeper purposes and insight. Especially, in order to build powerful awareness of political communication message and reach out the younger generation.

Indonesia was totally surprised back in 2014 when President Joko Widodo inaugurated Susi Pudjiastuti as the new Indonesian Minister of Marine Affairs and Fisheries (Kementerian Kelautan dan Perikanan, KKP). For the first time, she caught and snapped in pictures while enjoying her cigarettes at the terrace of National Palace after the ceremony. Those pictures were gone viral on social media and brought the public into massive curiosity about her. Little did they know, she has many more surprises to come.

During her term of service in Kabinet Kerja (President Joko Widodo's government cabinet, 2014-2019), she remains a polarizing figure in social media for her concrete and extreme action, while declaring war on foreign fishing boats that had encroached on territorial waters and threatened some of the world's most biodiverse seas (Beech and Suhartono, 2018). By holding on firmly to The United Nations Convention on the Law of the Sea (UNCLOS), she protects Indonesia's exclusive economic zone by commanding strictly to blow up and sink those illegal fishing boats. None of Indonesia's previous ministers ever did this. Foreign Policy named her name one of the 2019 Global Thinkers for saving the archipelago (Tepperman, 2019). Hence, she is known for her notorious hashtag in social media; \#Tenggelamkan (Sink It!).

In conjunction with Susi Pudjiastuti's sustainable mission, she has been actively using her social media as a prime digital communication strategy platform to build maritime security awareness in Indonesia. Dominantly on Instagram and Twitter, she tells stories about how we can save and support local fishermen from illegal fishing, cleaning up the coastline from plastic and pollution, stand up for our territorial waters, solving the problem of climate change, raising the bar of the blue economy from sea tourism, and even so much more. On top of that, she opens herself for digital interactive dialogues as well. Her followers are allowed to ask many questions regarding her 'thug' action, critical thinking, and tough commitment (Kumparan, 2018). And she is willing to answer it in her own way. 
All of these reasons ultimately became a powerful background of why she turned into a breakthrough figure in social media. For instance on Twitter, when people were commenting about the prohibition of lobster baby hunting or asking for her help to provide tuna fishing gear in Mentawai islands, she quickly responded to follow up soon (Twitter, 2019).

To put it on the same page, Christian Bueger (2014) in his academic journal called Marine Policy has defined maritime security as a global term which being used to explain new challenges in the international maritime domain and international relations in general. He explained that maritime security refers to some essential threats such as maritime inter-state disputes, maritime terrorism, piracy, human trafficking, smuggling, arms proliferation, illegal fishing, environmental crime, even maritime accident and disaster.

Two-thirds of Indonesia's territory consists of the waters. With this geographical condition, logically, building maritime security is not just an option. It is the frontline of sovereignty. Furthermore, humans rely enormously on the oceans every single day. From an economic perspective, marine resources deliver a huge contribution to national development (Wahyono, 2009).

Indonesia as the largest archipelago countries in the world came to realization and consensus of having law fundamental protection for the oceans since 1957 during Djuanda Declaration (Wahyono, 2009). Back then, there was no such thing as maritime security yet. But later, it was contributing significantly to the thoughts in the UNCLOS 1982, which formally became such a strong foundation and recognition, for the awareness of maritime security. After that, the acknowledgment of the Exclusive Economic Zone (EEZ) has been contributing a major positive impact for Indonesia. As an archipelago and developing country, managing maritime security is a fundamental key to increase better prosperity, economic growth, and national stability.

But in line with its geographical advantage, for many decades Indonesia's territorial waters have been facing many types of intentional and unlawful damages (Marsetio, 2015). Foreign fishing boats trespassing back and forth with no consequences. Industrial pollution disembogues every day. Sea animals stranded and died at the coastline, tangled by plastic rubbish. Endangered species are being killed for export business. And even so much more complexities (Metro TV, 2019). Big question is, how can maritime be the axis and front gate of archipelago country if there are layered global threats onto it?

In order to manage and develop maritime sustainability, Indonesia needs to prioritize maritime security for sure. Maritime security in fact is also the main focus and mission priority under Indonesian Ministry of Marine Affairs and Fisheries (Kementerian Kelautan dan Perikanan, KKP). It is their responsibility, function, and authority to actualizing Indonesia's marine sovereignty, sustainability, and prosperity. And it has been mandated and mentioned by legislations in the country. Some of them are Undang- 
Undang Nomor 32 Tahun 2014 about Maritime, Keputusan Presiden (Presidential Decree) Nomor 147 Tahun 1999 about Department of Marine and Fisheries Exploration, Peraturan Presiden Nomor 47 Tahun 2009 about the Ministry of Marine Affairs and Fisheries (Kementerian Kelautan dan Perikanan Republik Indonesia, 2019).

Although maritime security issues have been existing for many years and have the urgency as mentioned above. Ironically, very few Indonesians have the awareness and comprehensive understanding of it. Let's take an example from what happened in Trenggalek, East Java. This coast is known for its premium lobster quality for many years. One big and adult lobster can cost up to IDR 4,000,000 (US\$279) for each. Unfortunately, a lot of fishermen have been brutally hunting the seeds of baby lobster, to be exported to Vietnam with cost only IDR 10,000 - 100,000 (less than US\$ 7) per seed (Pudjiastuti, 2019). Why did they do this? Because they do not aware and understand yet for what its worth. This case simply has proven an incomprehension of people regarding IUU Fishing policy (Kumparan, 2019).

The minimum socialization about maritime security in Indonesia also became one of the reasons for this situation. Whereas, educating people can be a good start to open their mind and to change the way they treat their environment. People are having trouble to be discipline and contribute to protecting the sea because, for some reasons, they do not know and do not get used to it yet. Shortly, a very lack of maritime security awareness.

The objective of this research is mainly to analyze how Susi Pudjiastuti made a virtual approach and socialization about maritime security awareness through her social media official account. To find a mutual comparison between Susi Pudjiastuti's Instagram and Twitter official account. To criticize the result of Susi Pudjiastuti's communication strategy for this issue. So in the future, digitalization can be optimized and perfected in a better way, not only for maritime security but also for another political communication strategy.

\section{METHOD}

This research is developing a mixed-methodology with descriptive paradigm. There are two main purposes here. One is because this research would like to focus on capturing the way Susi Pudjiastuti has been utilizing her social media platforms in order to build maritime security awareness towards her followers. Two, this research is trying to measure (how much) and describe (how) the effectiveness of this type of communication strategy.

By developing a mixed methodology, the researcher used a convergent design to compare findings from qualitative and quantitative data sources (Wisdom \& Creswell, 2013). This research involves collecting both types of data at roughly the same time, assessing 
information using parallel constructs for both types of data, separately analyzing both types of data, and comparing results through procedures such as a side-by-side comparison in a discussion, or jointly displaying both forms of data. For example, the researcher collected quantitative data from a survey and/or social media listening tool (insight statistics), also the freedom to explore personal experiences of Susi Pudjiastuti's followers on Instagram and/or Twitter as qualitative data. Wisdom \& Creswell (2013) pointed out that these two types of data can provide validation for each other and create a solid foundation for drawing conclusions.

The initial process of quantitative data collection used a document study as secondary data. The researcher tried to collect information by using Social Media Listening. This term refers to a digital monitoring and analyzing process of social media channel by optimizing data with certain software and/or tool (Amaresan, 2018). The objective is to find out digital analytics report inside Susi Pudjiastuti's social media. Because it provides insight statistics from activity, content, hashtag, to audience that involves within.

The next data collection technique is through a questionnaire. It became the source of primary data. Here, the researcher tried to formulate a list of questions or statements based on the study objective, then measure the answers by using the Likert Scale.

After getting quantitative data respondent, the researcher has filtered and invited 3-5 of them to join the discussion. Lokananth Mishra (2016) in her journal mentioned that Focus Group Discussion is a type of in-depth interview accomplished in a group, led by a moderator, whose meetings present characteristics defined with respect to the proposal, size, composition, and interview procedures. Mishra also said that the discussion usually relies on an outline, or moderator's guide, to ensure that all topics of interest are covered. The researcher's objective is to find out much more spontaneous interactions, responses, explanations, and thoughts inside the group regarding certain questions or statements.

The amount of Instagram population for this research came from the total Instagram Followers of Susi Pudjiastuti's official account, and that is 2.000.000 Followers by June 2019. In order to determine sample size, this research used Slovin's formula (1960). This type of formula has been used to calculate proportional sample size and still representative of the population. The amount of respondent (sample) came from the total population $(\mathrm{N})$, divided by $1+(\mathrm{N})$ times quadratic $20 \%$ margin of error. Insert the total amount of population which is 2,000,000 Followers. And the margin of error is $20 \%$. Therefore, the result is 24,99 samples, rounded into 25 samples, which means the researcher must have at least 25 different individuals who have followed Susi Pudjiastuti on Instagram (25 Followers).

The amount of Twitter Population for this research came from the total Twitter Followers of Susi Pudjiastuti's official account. And that is 970,803 Followers by June 2019. Using Slovin Formula, the researcher inserted the total amount of population which is 970,803 
Followers. And the margin of error is 20\%. Therefore, the result is 24,99 samples, rounded into 25 samples, which also means the researcher must have at least 25 different individuals who have followed Susi-Pudjiastuti on Twitter (25 Followers). So, under the population of Susi Pudjiastuti's social media, there are in total 50 followers; 25 from Instagram and 25 from Twitter as Questionnaire respondent.

As for the base of theroretical framework, this research has combining some different theories. The first one is Governmental Communication Theory by Canel \& Sanders (2013), which pointing to the aims, role, and practice of communication implemented by executive politicians and officials of public institutions in the service of a political rationale. Referring to two-way communication form, it can be an interactive process which focusing on political information exchange among politician, media, institution, government policy, and the public itself. There are active feedback and response going back and forth. Interaction and transparency. And it represents another dynamics of what group communication should be.

The researcher also took a point of view from New Media Theory by Marshall McLuhan. He was specifically assumed that new media will no longer be used as an information transmitter only, but it will indeed change the relationship between humankind and their world (Griffin, 2003).

And the last theory is Humanistic Leadership Model by Robert Blake and Jane Mouton, Rensis Likert and Douglas McGregor. Generally speaking, this theory draws attention to leadership core function, which is to fulfill what people actually need in their lives, and that can be possible to achieve through a good interaction from both government and its people (Kartono, 2016). Humanistic Leaderships Model reflected on the way Susi Pudjiastuti chosed her communication strategy. Due to the lack of maritime security awareness in Indonesia (a situation to be fixed), she decided to build a good interaction directly with people through the power of social media instead just following conventional previous protocoler. So that people get a better understanding and can easily contribute their thoughts and/or actions to support each of Susi Pudjiastuti's campaign.

\section{RESULTS AND DISCUSSION}

Let us start the very first finding through a document study (secondary data) called Social Media Listening. This type of analytics tool has been utilized in digital marketing platform all over the world, including a personal branding in social media. There are 2 sources of Social Media Listening tools that are chosen by the researcher to be used in this document study. The first one is the Phlanx, a digital analytics generator that will cover data insight from Susi Pudjiastuti's Instagram. The second one is Keyhole, a digital analytics generator that will cover data insight from Susi Pudjiastuti's Twitter. 
According to the Phlanx analytics report, as of June 2019, Susi Pudjiastuti's Instagram has reached more than 2,3 million followers. She became the most followed Indonesian minister on Instagram. Not only during Kabinet Kerja term of service, in 2014-2019, but also the history of Indonesian governance (Instagram, 2019).

The second significant number from the Phlanx analytics report is about the Engagement Rate. Hopper (2019), an Instagram Planner company based in the United Kingdom, defined Engagement Rate as the percentage value which is used to measure the account and/or content performance on social media. It is calculated from the total quantity of interactions many as a number of likes, comments, impressions, reaches, saves, and shares.

\section{Quantitative}

Susi Pudjiastuti's Instagram is indicating 6,34\% of Engagement Rate on a daily basis (Phlanx, 2019). With at least 145,000 average likes and 2,300 average comments on each post. Also, it is far exceeding the average Engagement Rate on Instagram. Usually, with more than 1 million followers, the average Engagement Rate is not even more than $1,97 \%$. But she made it 3 times better. Statistically, she has succeeded to build such a great value of interactions on Instagram.

Fig 1. Susi Pudjiastuti's Engagement Rate on Instagram

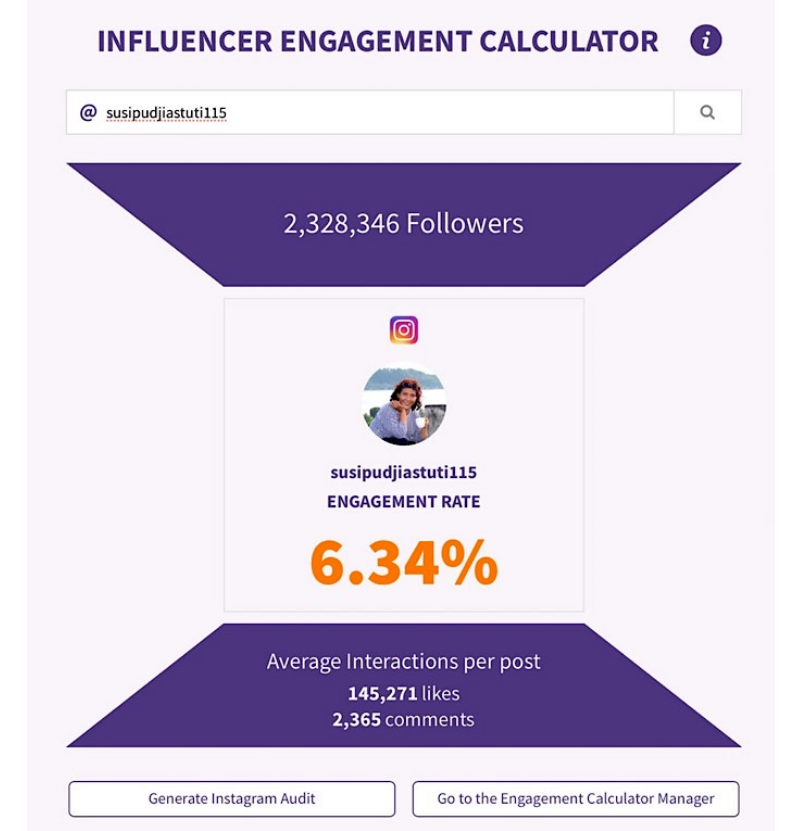

Source: Phlanx Instagram Engagement Calculator, 2019

The common formula for calculating Instagram Engagement Rate is coming from the total amount of interactions (likes, comments, shares), divided by total followers, then multiply by 100 (Hopper, 2019). 
The third data insight that researcher tracked from the Phlanx analytics report is the editorial content of Susi Pudjiastuti's Instagram. With this huge number of followers, she has been frequently using Instagram as one of her main social media platforms to communicate her works. Overall calculated, $78,81 \%$ of her posts were talking about Maritime Security, from IUU fishing, blue economy, climate change, to water pollution. The next content is $10,76 \%$ regarding Government Protocols, such as socialization of political policy, voluntary mission, and social work. The rest $10,41 \%$ consists of others like a personal post, KKP's greetings, public lecturing, media coverage, and travel post.

Fig 2. Susi Pudjiastuti's Instagram Editorial Content SUSI PUDJIASTUTI'S INSTAGRAM EDITORIAL CONTENT (AS OF JUNE 2019)

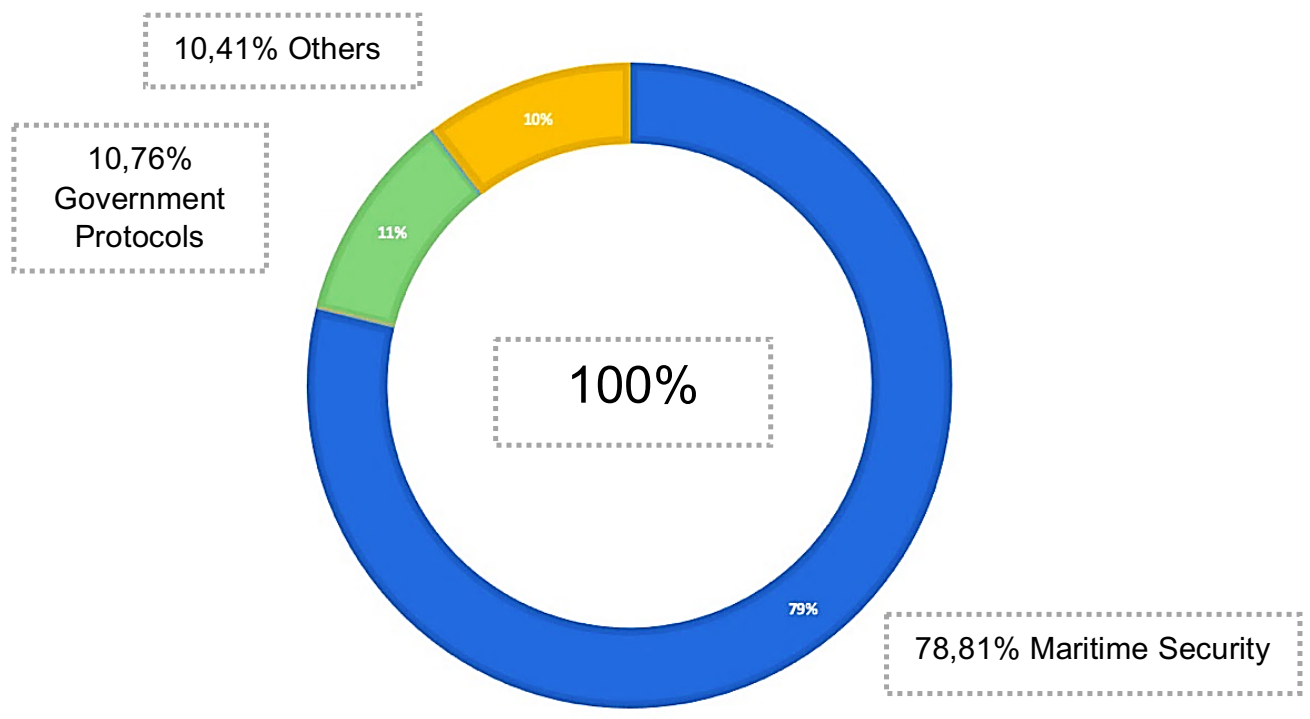

Source: Phlanx Instagram Engagement Calculator, 2019

Moving on to Twitter. According to the Keyhole analytics report, as of June 2019, Susi Pudjiastuti's Twitter has surpassed 970,000 followers, with more than 23,000 posts. Each daily post, she got at least 600 average likes, 200 average retweets, and 0,09\% average Engagement Rate. An Engagement Rate of Twitter which resulted between $0.02 \%$ and $0,09 \%$ is considered to be good (Kell, 2019). This means there are 2-9 average reactions for every 1,000 followers.

Another interesting finding from Susi Pudjiastuti's Twitter is about the main function which quite different compared to her Instagram. By looking at the Frequent Post and Media Types. The Reply number, 52,53\%, is dominating the post instead of New Tweet and Retweet. Also, 61,54\% is using a text medium instead of a photo or link. This means that she has been focusing this platform to gain more interactions through conversations (reply and text) with her followers. Not just to inform something as she does on Instagram. 
Fig 3. Susi Pudjiastuti's Twitter Tracker

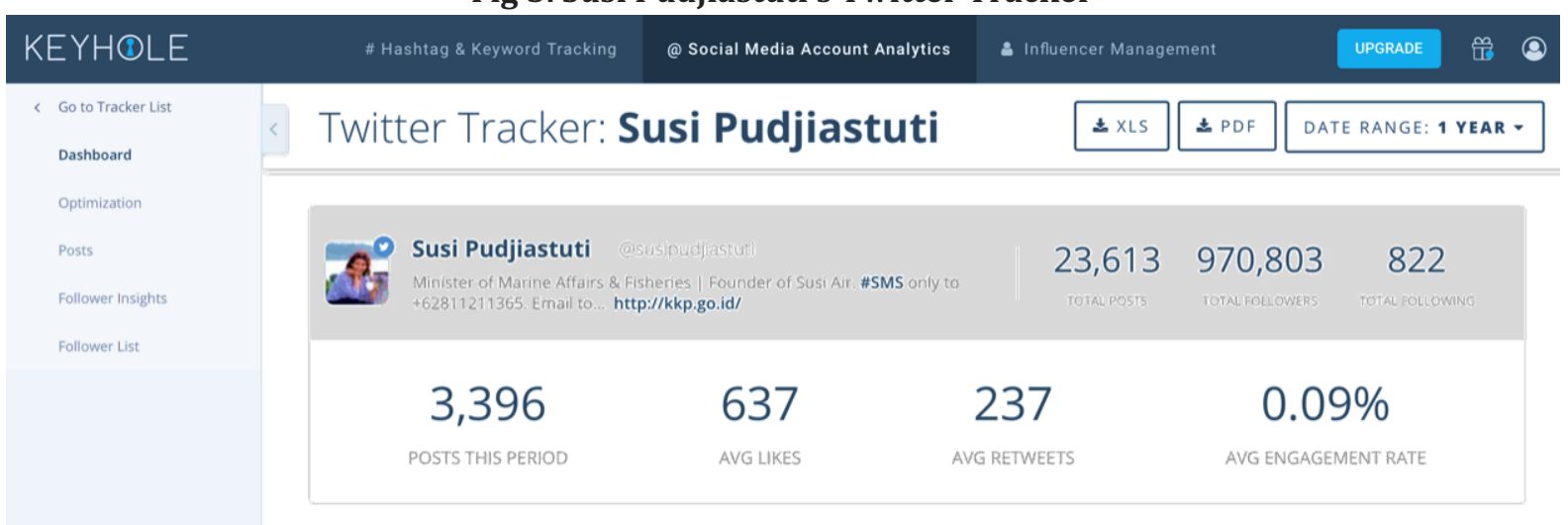

Source: Keyhole, Twitter Tracker, 2019

As for qualitative part, within 2 weeks, the questionnaire had collected data from 104 respondents (Susi Pudjiastuti's social media followers) by using an online survey administration-application named Google Form.

According to the result of Age (Usia) indicator, the biggest respondents came from 26-35 years old (adults); 52,9\% and 19-25 years old (young adults); 25\%. Then, the third category is $20,2 \%$ from people above 36 years old (middle-aged adults). Followed by the fourth category with only 1,9\% of people under 18 years old (teenagers). Another indicator is Sex (Jenis Kelamin) which shows that $55,8 \%$ of Susi Pudjiastuti's social media followers are women and the rest 44,2\% are men. Meanwhile, Occupation (Pekerjaan) indicator is dominated $52,9 \%$ by the employee, as the combination of blue-collar and white-collar. There are also $16,3 \%$ of the entrepreneur, $13,5 \%$ of the student, $11,5 \%$ of others (freelance, unemployment, retired), and the smallest one is $5,8 \%$ of the housewife.

In this Respondent Profile part, the researcher also has filtered respondents by some criteria, such as they have to be an active social media user and follower of Susi Pudjiastuti's social media account. Otherwise, they will not be able to continue to the next questionnaire part.

The second variable is focusing on responses regarding the benefit and usage of social media. More than $90 \%$ of respondent agreed that social media has become an alternative to new media that is needed by the public. They agreed that social media gives convenience to access the latest information the fastest possible way. Most of them have tried and felt the benefits of using social media on a daily basis. One of their motives is because they want to know and/or enrich important information that is happening around them. Also, they eventually decided to choose which social media account to be followed to get the right information.

The third variable is capturing the figure of Susi Pudjiastuti as one of the state officials and/or politician in Indonesia who has been utilizing her social media platform and giving transparency access to people to get to know her daily work better. More than 
95\% of respondent found out about Susi Pudjiastuti's figure from social media and decided to follow her account on purpose to get to know more information directly from her. They are claimed to be happy to finally have the figure of Indonesian minister like Susi Pudjiastuti. Not only because of her character, but also because of her governmental transparency to be actively sharing her daily work in public.

Next variable is focusing on the maritime security awareness. Almost $60 \%$ of respondents agreed that they did not know anything about the importance of maritime security before they are following Susi Pudjiastuti's social media. There are 96,1\% of them who realize that there is a great deal of valuable information regarding maritime security on her social media account. This variable also revealed $98 \%$ of them agreed that she has frequently been proactive in socializing things about maritime security.

From a deeper perspective of maritime security, most respondents interestingly considered some important messages from Susi Pudjiastuti's social media account. They agreed on how it has educated them that some actions like illegal fishing and/or trespassing foreign boats to Indonesian water territory are strictly forbidden and can be punished by the law in Indonesia. It has enlightening their mind that the blue economy (fishes, minerals, energy, sea tourism, sea transportation) has so many great benefits for the country. They even understand better that climate change and pollution have negative impacts on the ocean. Shortly, the content information about maritime security awareness addressed by Susi Pudjiastuti on her social media has been able to reach more people in Indonesia.

Fig 4. Questionnaire Insight: Susi Pudjiastuti and Maritime Security Content

\section{Dari akun media sosial Susi Pudjiastuti, kini saya semakin tahu bahwa masuknya kapal asing ke perairan nasional itu dilarang dan ada hukumnya di Indonesia.}

\section{4 responses}

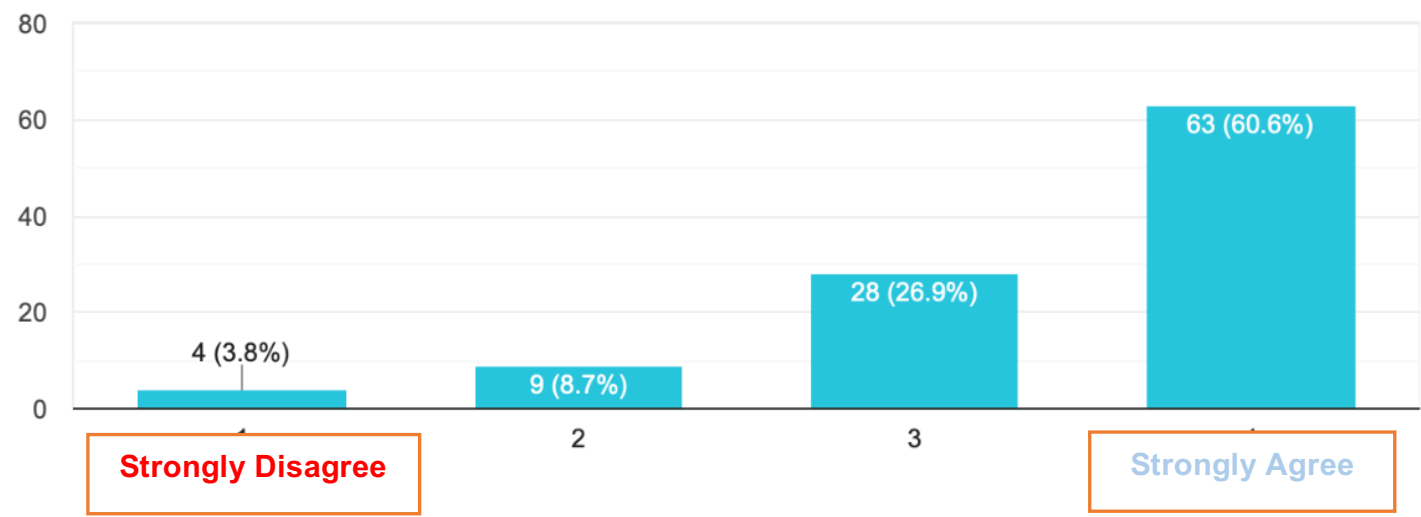

Source: Researcher, 2019 
From cognition perspective, this finding confirms that more than $98 \%$ of the respondent can easily remember and understand the importance of maritime security through the consistency of Susi Pudjiastuti's social media account.

As for the affection perspective, it is counted around 97,1\% of the respondent can feel the anxiety and emotion to support Susi Pudjiastuti to enforce the law of maritime security in Indonesia. Even $99 \%$ of them are motivated to become more aware and care about Indonesian water territory because of her social media content.

The effectiveness of Susi Pudjiastuti's communication strategy also has seen by the last indicator; behavior. About $81,8 \%$ of respondent love to appreciate her social media content by doing small actions such as giving likes, comments, reply, retweet, and/or sharing with their other friends in social media. In other words, by using this communication strategy, Susi Pudjiastuti made the right moves to reach more people to get a better comprehension of maritime security awareness in Indonesia.

Fig 5. Questionnaire Insight: The Effectiveness
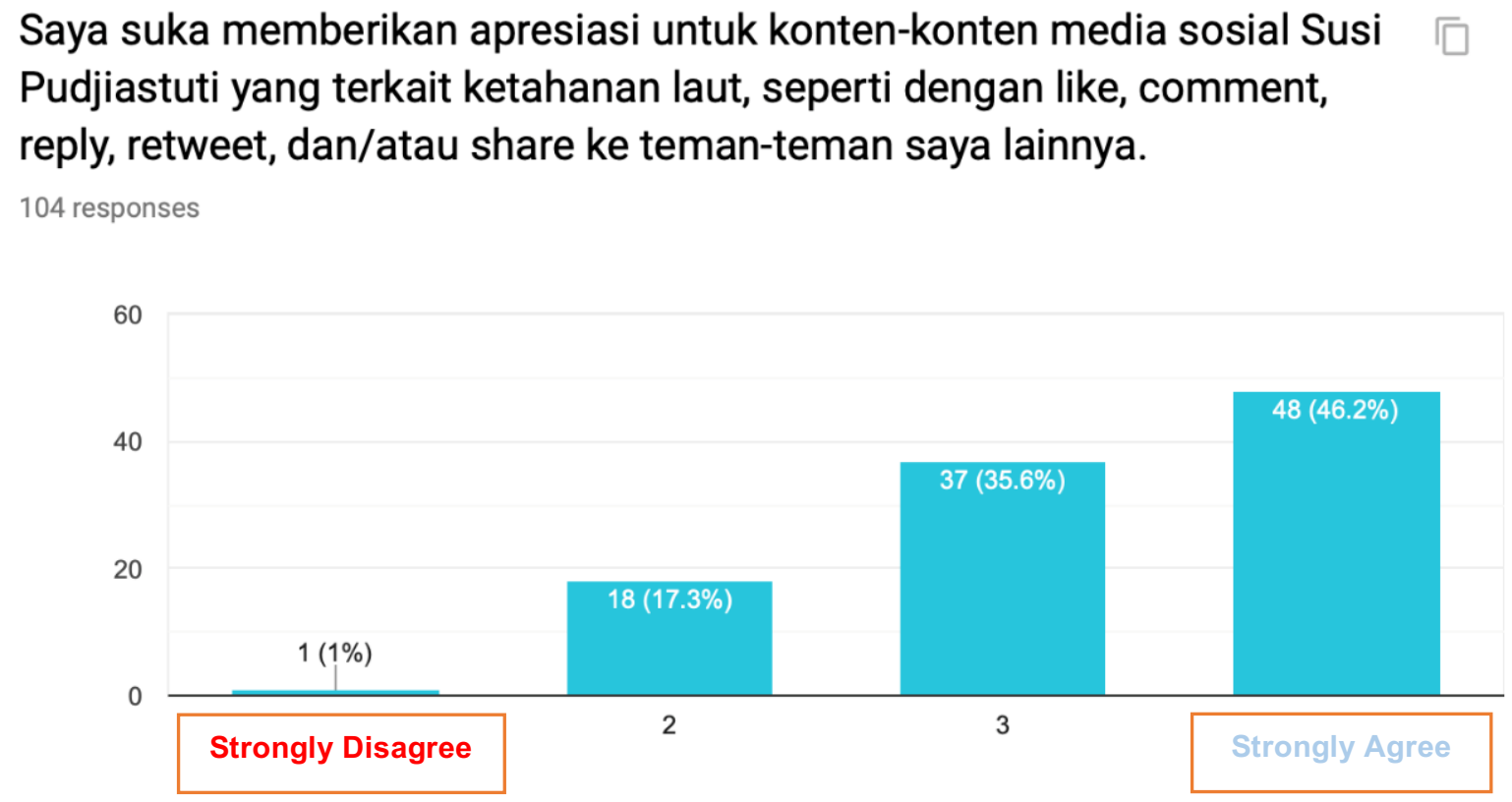

Source: Researcher, 2019

\section{Qualitative}

From 104 questionnaire respondents who had participated previously in the quantitative phase, the researcher has selected 5 of them randomly to join the session of Focus Group Discussion as participants. The objective is to get a more comprehensive testimonial, argument, opinion, and/or idea regarding the research focus, which later will be utilized as the second primary data. 
The researcher firstly asked the group to introduce themselves one by one. Including to mention their name, age, and occupation so it can be matched with their previous questionnaire answers. And they are: (1) Farischa, 24 years old, employee (logistic officer), Surabaya, East Java. (2) Meinar Utowo, 28 years old, employee (reporter), Jakarta, DKI Jakarta. (3) Destya Ninggeni, 32 years old, others (freelance photographer), Denpasar, Bali. (4) Hernawan Arianto, 33 years old, entrepreneur, going back and forth between Jakarta, DKI Jakarta and Padang, West Sumatera. (5) M. Bisir Sudrajat Fuad, 20 years old, student, Makassar, South Sulawesi.

These 5 participants are all active social media users and have been following Susi Pudjiastuti's social media accounts; Instagram and/or Twitter. Meinar and Hernawan, for instance, have become followers since 2015 after Susi Pudjiastuti gained high popularity for her rebel action and social media hashtag \#Tenggelamkan.

When the researcher was asking about the benefit and usage of social media, the group came into a solid response. They are all agreed that social media makes many types of information travel faster than ever. People can easily access whenever and wherever they want. No more distance issue. Second, social media also made networking expansion to become possible across cities and countries. Conventional media like television always has its gatekeepers. They always decide what people suppose to see or not. But social media broke this old pattern. Now people have the power to choose which one they want to follow and which information can be trusted. Especially with so many hoax potentials nowadays.

The next discussion will be framing the figure of Susi Pudjiastuti as the Indonesian Minister of Marine Affairs and Fisheries who utilizes her social media platform and giving transparency access to people to get to know her daily work better. Most of them said that she is a sensational, frontal, rebellious, quirky, one of a kind governmental figure. Bisir even considered her as a Wonder Woman of Indonesia who seemed to be very tough to accomplish her job. Hernawan believes that she brought many changes in Indonesia political scene. Not that typical of most conservative bureaucrats. Farischa and Destya were addressing their admiration during her term service, she has proven so many concrete work results without any compromise. Meanwhile, Meinar stated that, "I used to keeping up some news about her (Susi Pudjiastuti). I think the most impressive one was her frontal action to fight those foreign illegal boats and saying "Sink it!". It became memes and hashtags everywhere, right? No matter what, "Sink it!".

Participants also came into one consent that Susi Pudjiastuti has been carrying an impressive achievement as a minister. They said, it takes huge courage, commitment, logic, practical thought, and firmness to be like her. Moreover, with a massive scope of responsibility to watching over Indonesia the archipelago, all the way from Sabang to Merauke. 
By doing social media activation as a political communication strategy, all participants conclude that Susi Pudjiastuti has succeeded in creating public impressions. People curious and want to get to know her daily life through her social media. And she gives people what they need with her frequent contents. Unlike the other politicians, she does not mind to transparently share about her governmental duty and responsibility. These are also some strong reasons why people decided to follow her social media. So yes, indeed, social media activation plays the main role that contributes to what people think about her.

Narrowing down to maritime security awareness which does exist as in her social media content. The researcher asked the group about what kind of information they have seen, heard, and/or read so far from Susi Pudjiastuti's social media. And their pick-up points are (1) Trespassing foreign boats in Indonesian water territory. (2) Illegal fishing, especially the ones with bombing or other dangerous explosives used by local fishermen on purpose. (3) Site and/or island visits to remote areas in Indonesia. Including some inspections to fishermen and local fish markets which related closely to the blue economy point of view. (4) Marine tourism places that have not been exposed yet. (5) Plastic pollution. Inviting everyone to use less plastic in daily life. (6) Susi Pudjiastuti's personal post like traveling with her granddaughter, doing hobbies like paddling and yoga, etc.

Most of the contents are talking about maritime security. Through Susi Pudjiastuti's social media content, people are being educated and awaken that those threats upon maritime security are, in fact, an organized international crime that must be handled seriously.

Previously, Meinar and Destya are both quite familiar with maritime security issues like illegal fishing, smuggling, or tidal energy. But they admitted how some of these issues started to raise on the surface after Susi Pudjiastuti brought the conversation to public. Meinar also agreed, "It is amazing Susi Pudjiastuti did such a great socialization through her social media from time to time. She encourages people not to be afraid of any threats from outside because that is an important message to the world that Indonesia has its own sovereignty."

First base from the cognition perspective, participants mostly agreed that this communication strategy helped them to remember the importance of maritime security. With its content consistency, they became more aware and critical about this issue. For instance, Hernawan understands better by saying, "Now I became much more thoughtful about how every single human action on the land can really affect the ocean sooner or later. Even it is only coming from a single-use plastic at my house, the one that is far away from the beach, it can be ended up to the bottom of the ocean."

The next one is about affection. At some point, Hernawan and Meinar felt a fit of anger and furious when they found out many violations happened to Indonesian waters. But they salute Susi Pudjiastuti for her decisive action. Basir got the feeling to be more critical 
because of the content. Farischa is completely touched by the fact of having such a hardworking figure like Susi Pudjiastuti. Destya, on the other hand, is motivated to be more concern since maritime security related closely to marine tourism, which is leading to her job as a photographer in Bali. She added tourist comes all the way to Bali to enjoy the ocean. If the ocean is polluted and destroyed, it will be affecting her job as well.

Last one, the effectiveness of Susi Pudjiastuti's communication strategy also can be seen from the third indicator; behavior. All participants did some little actions Susi Pudjiastuti's social media content such as giving likes, comments, reply, retweet, and/or sharing with their other friends in social media. If the content is good, then they will certainly show appreciation by doing such things. And that is what social media is all about. Reaching out as many people as possible. Destya even did it simply because she likes the figure of Susi Pudjiastuti.

Other than that, some participants also tried another action as the result of better maritime security awareness. Destya and Farsicha have been doing the plastic diet for small things like a water bottle or shopping bag. Destya convincely committed, "I have stopped from the habit of buying plastic bottle because of it (maritime security awareness). Each time I go to a coffee shop or restaurant, I try my best not to use anymore plastic straw either. We should all have a plastic diet!"

It might all seemed like small stuffs, but those things are real starters to achieve the effectiveness of this whole communication strategy of building maritime security awareness.

\section{CONCLUSION}

With the current and upcoming progressive technology in the world, it can be a great potential and symbiosis to strengthen the awareness of so many international issues. Human has reached the era where terabytes of communication message can be transferred remotely and easily. Including political communication mission like maritime security awareness in Indonesia. So yes, if the objective is to get people's awareness as wide as possible, then utilizing social media as a communication strategy is no longer just an option. It is a must.

\section{Social Media Utilization}

Susi Pudjiastuti has made a concrete virtual approach through social media platform. Her posts on Instagram, are dominantly filled by the effort of introducing and/or socializing maritime security awareness in Indonesia through photo, video, and informative caption. Alongside with many governmental messages regarding her daily duty as a minister. Meanwhile on Twitter, she has been channeling this platform to gain more interactions by creating a great value of conversations (reply and text) with her followers. This 
communication strategy is certainly strengthening the existency of each other. Because each social media has a different approachment.

\section{Maritime Security Awareness}

(a) The content information about maritime security awareness addressed by Susi Pudjiastuti on her social media has been able to reach more people in Indonesia. (b) People can easily remember and understand (cognition) the importance of maritime security through the consistency of Susi Pudjiastuti's socialization in social media. (c) People are motivated to become more aware and care (affection) about Indonesian water territory because of Susi Pudjiastuti's social media content too. (d) People love to appreciate Susi Pudjiastuti's social media content by doing small actions (behavior) such as giving likes, comments, reply, retweet, and/or sharing with their other friends in social media. But further than that, as the result of better maritime security awareness, people also start to bring the action to their real lives as well, like contributing to marine tourism or reducing plastic pollution.

\section{Theoretical Combination}

The optimization of e-Government can be reflected on the way Susi Pudjiastuti uses the power of new media. She has building maritime security awareness as an urgent political communication issue that can be easily digest by the public through social media. She also broke the long chain of bureaucracy and conservative protocol rules as a state official. She made a government transparency so that people can have a better and direct interaction. This package of political communication strategy is a combination of 3 fundamental theories of this research in the beginning; Governmental Communication, New Media, and Humanistic Leadership Model.

\section{REFERENCES}

Amaresan, S. (2018). Why is Social Listening \& Is It Important? HubSpot: Social Media Listening Tool Software.

Beech, H. \& Suhartono, M. (2018). A 'Little Bit of a Nut Case' Who's Taking on China. The New York Times: Asia Pacific, Saturday Profile. Retrieved from March 16, 2019 : https://www.nytimes.com/2018/06/08/world/asia/indonesia-fishing-boats-chinapoaching.html

Bueger, C. (2014). Marine Policy. Department of Politics and International Relations, School of Law and Politics, Cardiff University.

Canel, M. J. \& Sanders, K. (2013). Government Cases and Challenges Communication. Bloomsbury Academic, New York.

Flew, T. (2005). New media: An introduction South Melbourne: Oxford University Press.

Fortune Magazine. World's Greatest Leaders. (2018). Retrieved from March 16, Ads 2019 : http://fortune.com/worlds-greatest-leaders/ridwan-kamil-48/ 
Griffin, E. A. (2003). A First Look at Communication Theory. Fifth edition, page 341-354. New York: McGraw-Hill.

Hopper. (2019). Social Media Marketing Glossary: Engagement Rate. Retrieved from June 17, 2019: https://www.hopperhq.com/social-media-marketing-glossary-2018/engagementrate/

Instagram. (2019). Profile of Susi Pudjiastuti's Official Account. Instagram: Social Networking Service, Facebook, Inc. Retrieved from April 23, 2019: https://www.instagram.com/susipudjiastuti115/

Kartono, K. (2016). Pemimpin dan Kepemimpinan: Apakah Kepemimpinan Abnormal Itu? Jakarta: PT RajaGrafindo Persada, Cetakan 21.

Kell, L. A. (2019). How to increase rates of Engagement Rate on Twitter? ITP Live, influencer marketing and digital talent agency. Retrieved from June 23, 2019: https://itp.live/content/3089-does-your-twitter-account-have-good-engagement

Kementerian Kelautan dan Perikanan Republik Indonesia. (2019). Profil: Visi dan Misi. Retrieved from June 16, 2019: https://kkp.go.id/page/7-visi-dan-misi

Kemp, S. (2018). Digital in 2018: World's Internet Users Pass the 4 Billion Mark, Special Report. We are Social. Retrieved from April 19, 2019: https://wearesocial.com/blog/2018/01/globaldigital-report-2018

Keyhole. (2019). Retrieved June 17, 2019: https://keyhole.co

Kumparan. (2018) Susi Pudjiastuti dan Langkah Skak Mat di Media Sosial. Kumparan News, Video News. Retrieved from April 14, 2019: https://kumparan.com/@kumparannews/susipudjiastuti-dan-langkah-skak-mat-di-media-sosial-27431110790550001

Marsetio. (2015). Kerjasama Menghadapi Ancaman Terorisme di Perbatasan Laut dalam Menjaga Stabilitas Keamanan Maritim Kawasan. Public Lecture, Civitas Akademika Universitas Sumatera Utara, Medan.

Metro TV. (2019) The Nation: Susi - Prestasi, Kontroversi, dan Ambisi. Retrieved from Youtube April 14, 2019: https://www.youtube.com/watch?v=S5lFg_XOoA

Mishra, L. (2016). Focus Group Discussion in Qualitative Research. TechnoLEARN vol. 6. Mizoram University, India.

Phlanx. (2019). Retrieved June 17, 2019: https://phlanx.com

Riaz, S. (2010). Effects of Media Technologies on Political Communication. Journal of Political Studies, Vol. 1, Iss. 2.

Tepperman, J. (2019). A Decade of Global Thinkers. Foreign Policy. Retrieved from March 16, 2019: https://foreignpolicy.com/2019-global-thinkers/

Twitter. (2019) Profile of Susi Pudjiastuti's Official Acctount. Twitter: Social Networking Service, Twitter, Inc. Retrieved from April 23, 2019: https://twitter.com/susipudjiastuti

Twitter. (2019). FAQ. Retrieved from April 17, 2019: https://help.twitter.com/en/usingtwitter/twitter-sms-faqs

Wahyono, S.K. (2009). Indonesia Negara Maritim. Teraju, Anggota IKAPI. 
We Are Social. (2018). Essential Insight into Internet, Social Media, Mobile, and E-Commerce Use Around the World. Global Digital Report, Pre Research Center.

Wisdom, J. and Creswell, J W. (2013). Mixed Methods: Integrating Quantitative and Qualitative Data Collection and Analysis While Studying Patient-Centered Medical Home Models. Rockville, MD: Agency for Healthcare Research and Quality. AHRQ Publication No. 13-0028EF. 